\title{
РУССКАЯ НАРОДНАЯ СКАЗКА КАК СРЕДСТВО ВОСПИТАНИЯ ВОИНА И ЗАЩИТНИКА ОТЕЧЕСТВА
}

\author{
П.Б. Зотов \\ ФГБОУ ВО “Тюменский государственный медицинский университет" Минздрава России, г. Тюмень, \\ Россия

\begin{abstract}
RUSSIAN FOLK TALE AS A MEANS OF EDUCATING A WARRIOR AND DEFENDER OF THE FATHERLAND
\end{abstract}

Контактная информация:

Зотов Павец Борисович - доктор медицинских наук, профессор (SPIN-код: 5702-4899; Researcher ID: U2807-2017; ORCID iD: 0000-0002-1826-486X). Место работы и должность: заведующий кафедрой онкологии ФГБОУ ВО “Тюменский государственный медицинский университет" Минздрава России. Адрес: Россия, 625023, г. Тюмень, ул. Одесская, д. 54; специалист центра суицидальной превенции ГБУЗ ТО "Областная клиническая психиатрическая больница». Адрес: Тюменская область, Тюменский район, р.п. Винзили, ул. Сосновая, д. 19. Темефон: +7 (3452) 270-510, эмектронный адрес (корпоративный): note72@yandex.ru

Contact Information:

Zotov Pavel Borisovich - MD, PhD, Professor (SPIN-code: 5702-4899; Researcher ID: U-2807-2017; ORCID iD: 0000-0002-1826-486X). Place of work and position: Head of the Department of Oncology, Tyumen State Medical University. Address: Russia, 625023, Tyumen, 54 Odesskaya str; Specialist of the Center for Suicidal Prevention of Regional Clinical Psychiatric Hospital. Address: Tyumen region, Tyumen region, r.p. Vinzili, 19 Sosnovaya str. Phone: +7 (3452) 270-510, email (corporate): note72@yandex.ru

Представлен оригинальный анализ русской народной сказки «Лиса и Заяц». В вводной части автором отмечены ряд условий, требуемых при толковании сказок: необходимость следования оригинальному сюжету; предпочтительный отказ от логических умозаключений; строгая локация сказки в социальную группу или условия, географию места или конкретный исторический промежуток, применительно к которым сказка начнёт раскрывать своё истинное назначение. Анализ, проведённый согласно этим условиям, показал, что первичный сюжет исследуемой сказки, может иметь более глубокий смыл и отражать этапы воспитания и подготовки защитника Отечества. Чтобы победить хитрого и коварного врага (Лиса) молодому неопытному воину (Заяц), необходимо пройти три этапа / уровня подготовки (Путь): стать физически сильным (Медведь), храбрым и мужественным (Волк) и принять, как вероятный исход ратного дела, свою смерть (Петух с косой). По ходу сюжета так же обсуждаются отдельные элементы сказки (Дом, печь и др.), что позволяет по-новому вглянуть на известное с детства народное произведение, понять его высокий духовный смысл. В заключении автор отмечает, что представленный анализ сказки не претендует на абсолютную однозначность её толкования и безусловность доводов, но позволяет обратить внимание на необходимость изменения отношения к национальной устной и письменной традиции, необходимость её изучения.

Ключевые слова: лубяная избушка, Лиса и Заяц, анализ сказки «Лиса и Заяц», психологическая подготовка воина, сказка, русская народная сказка, анализ сказки

Русские народные сказки отражают богатейший исторический, культурный и нравственный опыт, накопленный за многие века, передача которого по наследству в полном согласии с национальными традициями всегда представляла важную задачу для каждого поколения. Доступные детскому возрасту образы и сюжеты должны помочь понять базовые представления нашей культуры о добре и зле, чести и предательстве, а так же сформировать общее понятие о едином народе и Родине.
Russian folk tales reflect the richest historical, cultural and moral experience accumulated over many centuries, the transmission of which by inheritance in full accordance with national traditions has always been an important task for each generation. The images and stories accessible to children should help to understand the basic ideas of our culture about good and evil, honor and betrayal, as well as form a common concept of a united nation and homeland.

Unfortunately, the rapid development of science and technology often leads to the for- 
К сожалению, бурное развитие науки и техники, нередко ведёт к формированию упрощённого, часто снисходительного отношения к народным сказкам, что в целом, отрицательно отражается на сохранении и передаче этой многовековой устной и письменной культурной традиции. Частым заблуждением так же является представление о сугубо детском их предназначении, а, например, былины считаются уделом более старшего возраста. Между тем, народная сказка - это средство многоцелевого и многовозрастного назначения, и восстановление её задач и функций применительно, в том числе, к различным социальным группам, представляет собой большой интерес для исследователей.

При внимательном прочтении вдруг оказывается, что знакомая и любимая с раннего детства сказка имеет более глубокий смысл, а прежний простой сюжет проявляет многоуровневый характер. Действующие персонажи приобретают ранее не ассоциируемые с ними качества и свойства. В итоге, прочтение того же текста даёт новый уровень понимания сюжета, и, что самое важное, имеет более серьёзные, преимущественно духовные последствия для посвящаемого в таинства Слова.

Каждая сказка - это простой (специально максимально сокращённый), и, на первый взгляд, понятный сюжет, с простой, очевидной («очами видной») моралью. Тем не менее, первичный сюжет это лишь «золотой ключик», который будет иметь ещё бо̀льшую ценность только при нахождении того замка, который он должен открыть. Но поиск этого замка нередко становится мало выполним. Среди частых ошибок при попытке прочтения нарушение заложенного в сказке первичного кода (сюжет и герои). Сохранность этого кода - главное условие его работоспособности при раскодировании. Как пример, замена действующего персонажа на похожие образы (волка на собаку или несколько собак) или последовательность их появления в сказке, может нарушить весь смысл произведения. Другая ошибка - использование логического мышления. Следуя логике трудно понять глубокое разочарование Бабки и Деда при падении и расколе золотого яичка после неосторожных действий Мышки. Хотя накануне они предпринимали подобную попытку самостоятельно, но не достигли нужного эффекта, и также были недовольны (?!) неудачей (сказка «Курочка Ряба»).

Ключевое значение всё же имеет выбор локации сказки - тот самый замок, где сработает золотой ключик. В качестве «замка на потаённой двери», целенаправленно ведущего к запрограммиро- mation of a simplified, often condescending attitude to folk tales, which in general negatively affects the preservation and transmission of this centuries-old oral and written cultural tradition. A common misconception is also the idea of their purely childish mission, while, for example, epic stories are considered to be aimed at an older age. Still, a folk tale is a means of multipurpose and multi-age designation, and the restoration of its tasks and functions in relation to various social groups is of great interest to researchers.

Upon careful reading, it suddenly turns out that a fairy tale that is familiar and beloved from early childhood has a deeper meaning, and the former simple plot shows a multi-level character. Acting characters acquire previously unassociated qualities and properties. As a result, reading the same text gives a new level of understanding of the plot, and, most importantly, has more serious, mainly spiritual consequences for the sacred sacraments of the Word.

Each fairy tale is a simple (specially shortened as much as possible), and, at first glance, understandable plot, with simple, obvious ("visible to the eye") moral. However, the primary plot is just a "golden key", which will be of even greater value only if you find the castle that it should open. But the search for this castle is not often an easy task. Among the common mistakes when trying to read is a violation of the primary code laid down in a fairy tale (plot and heroes). The safety of this code is the main condition for its operability during decoding. As an example, replacing the acting character with similar images (a wolf for a dog or several dogs) or the sequence of their appearance in a fairy tale can violate the whole meaning of the tale. Another mistake is the use of logical thinking. Following the logic, it is difficult to understand the deep disappointment of Grandma and Grandfather during the fall and split of the golden egg after the careless actions of the Mouse. Although the day before they made a similar attempt on their own, they did not achieve the desired effect, and they were also unhappy (?!) with non-luck (the fairy tale "Ryaba Kurochka").

The key value is still the choice of the location of the tale - the very castle where the golden key works. As a "lock on a hidden door" purposefully leading to the programmed opening (enlightenment?) in the plot a social group or conditions, the geography of the place or a specific historical interval in relation to which the fairy tale begins to reveal its true purpose can act. Without running ahead of the topic relative- 
ванному в сюжете открытию (просветлению?), может выступать социальная группа или условия, география места или конкретный исторический промежуток, применительно к которым сказка начнёт раскрывать своё истинное назначение. Не забегая вперед относительно исследуемой в этой статье темы, для пояснения обратимся к зарубежному опыту. Например, при чтении известной сказки Шарля Перро «Кот в сапогах» у отечественного читателя может возникать вопрос относительно столь необычного для нас распределения наследства. В российских традициях наследство согласно родовому праву в большинстве случаев распределялось между сыновьями поровну, а дочери получали приданное при выходе замуж. В случае, если родители были живы до преклонного возраста, то оставались на попечение младшему сыну, которому, и доставался родовой дом. В сказке Ш. Перро совершенно другая ситуация: старшему сыну досталась мельница, среднему - осёл, младшему - кот. Почему так? Для понимания ситуации здесь и требуется историческое смещение сюжета - во времена Франции XVII века, когда была написана сказка. В средние века в наследственном праве Франции, как и большинстве европейских стран, наиболее характерным институтом был майорат (от лат. major - старший), согласно которому всё недвижимое имущество (в данном случае мельница) передавалось старшему сыну [1]. Остальные могли довольствоваться, либо ничем, либо какой-то частью движимого имущества - по усмотрению завещателя (осёл и кот). Такой порядок позволял избежать дробления и сохранять целостность основного имущества в одних руках (чаще речь шла о земельных владениях - феоде).

С учётом отмеченных выше условий попробуем прочесть заново старую русскую сказку «Лиса и Заяц», и понять какое отношение она имеет к воспитанию воина и защитника Отечества.

Вкратце напомним сюжет, разбив его на 2 части. В первой описывается обстановка и развитие «трагедии». Во второй - основной сюжет борьбы и развязка.

Часть 1. «Жили-были Лиса и Заяц. Была у Зайца изба лубяная, а у Лисы - ледяная. Пришла весна, изба у Лисы и растаяла. Попросилась она к Зайцу пожить. Да потом его и выгнала».

Часть 2. «Идёт Заяц по лесу и плачет, а на встречу ему Медведь. - Что ты Заянька плачешь? Как же мне не плакать? Была у меня изба лубяная, а у Лисы - ледяная. Пришла весна. Изба у Лисы растаяла. Попросилась она ко мне в дом переночевать, да потом и выгнала». Медведь откликнулся ly explored in this article, let us turn to foreign experience for clarification. For example, when reading a famous fairy tale by Charles Perrault "Puss in Boots", the Russian reader may have a question regarding the untypical for us distribution of inheritance. In Russian traditions, in most cases inheritance was distributed equally between sons according to the tribal law, and daughters received a dowry upon marriage. In the event that the parents were alive until old age, their youngest son stayed to take care about them, and received the family home. In the Perrault's tale, the situation is completely different: the eldest son got a mill, the middle son got a donkey, and the youngest got only a cat. Why so? To understand the situation here, a historical displacement of the plot is required to the 17 th century in France, the time when a fairy tale was written. in the Middle Age France, as well as in most European countries, the most characteristic institute of the inheritance law was a Majorate (from lat. Major - senior), according to which all non-movable property (in this case the mill) was transferred to the eldest son [1]. The rest could be content with either nothing or some part of movable property - at the discretion of the testator (the donkey and the cat). This order allowed us to avoid fragmentation and maintain the integrity of the main property in the same hands (more often it was about land holdings the feud).

Taking into account the conditions noted above, we will try to read the old Russian fairy tale "The Fox and the Hare" with a new perspective and try to understand what it has to do with raising a warrior and defender of the $\mathrm{Fa}$ therland.

Briefly recall the plot, breaking it into 2 parts. The first describes the situation and development of the "tragedy." The second depicts the main plot of the struggle and denouement.

Part 1. "Once upon a time there lived a Fox and a Hare. The Hare had a bast hut, and the Fox had an ice hut. Spring came, the hut of the Fox melted down. She asked to live with the Hare. Then she kicked him out."

Part 2. "A Hare walks through the woods and cries, and the Bear meets him. - Why are you crying, Little Hare? "How can I not cry?" I had a bast hut, and the Fox had an ice hut. Spring came. The hut of the Fox melted down. She asked to spend the night at my house, and then she kicked me out." The bear responded to the hare's misfortune, offering to drive the Fox out. The finale of this attempt is known - the Bear was frightened (?!) of Fox's threats and ran 
на беду Зайца, предложив изгнать Лису. Финал этой попытки известен - Медведь испугался (?!) угроз Лисы и убежал прочь. Подобным образом повёл себя и волк. Он, как и медведь, испугался (?!) лисы. Успешный финал сказки связан с петушком (?!). Его угрозы «посечи» косой Лису возымели эффект, она сбежала. Заяц вновь поселился в свой дом. Остался с ним и Петушок (?!). Здесь и сказке конец ...

На первый взгляд - добрая народная сказка с положительным концом для детей младшего возраста. Будет ли она интересна более старшему поколению? И какое отношение она может иметь к теме воспитания воина, защитника Отечества, вынесённой в название настоящей статьи?

Рассмотрим сюжетную линию более внимательно и отметим ряд на первый взгляд парадоксальных ситуаций, но, как окажется впоследствии, имеющих принципиальное значение.

1. Главный герой - маленький зайчик, но имеет хорошую тёплую лубяную избу, в которой не страшны морозы.

2. Лиса, напротив, жила в ледяной избе, которая по весне растаяла.

3. Заяц и лиса, судя по всему, соседи, знают друг друга - заяц сердобольный и пустил лису на постой, но потом, что-то пошло не так и он потерял свой дом.

4. Медведь и волк в природе сильнее лисы, но вдруг испугались её? Петух, напротив, - птица. Слабее, но смог выгнать лису, и в конце победить...?

5. Медведь и волк представлены в сказке в натуральном виде, а петух имеет дополнительный неодушевлённый предмет - косу?

6. Почему Лиса лежала на печи, имея прекрасную теплую шубу, а не смотрела, например, в окно, высматривая неугомонных гостей?

7. Петух после победы над лисой не пошёл дальше, а остался жить в доме вместе с зайцем ...?

Теперь попробуем немного обобщить возникающие вопросы. Сюжет развивается относительно помощи в освобождении жилища достаточно слабому члену сообщества (в данном случае лесного). При этом, согласно текста сказки, каждый из встречающихся на пути, проявляет внимание и уважение как к лично к нему (обращаются - «Заинька»), так и его беде. Стараются помочь. Но победа не приходит с медведем и волком. Напротив, динамика помощи идёт в обратную сторону, и побеждает не самый сильный (медведь) и агрессивный (волк), а наиболее слабый (петух), но имеющий очень важный атрибут, не связанный с видо- away. The wolf behaved the same way. Like the bear, he was frightened (?!) of the fox. The successful ending of the tale is associated with a Rooster (?!). His threats to "cut" the Fox with his scythe had an effect and she escaped. The Hare again settled in his house. Rooster stayed with him (?!). And here the tale is over ...

At the first glance it is just a good folk tale with a positive ending for young children. Will it be of interest to the older generation? And what relation can it have to the topic of educating a warrior, defender of the Fatherland, which is put forward in the title of this article?

Consider the storyline more carefully and note the series of what may seem at first paradoxical situations, but, as it turns out later, are of fundamental importance.

1. The main character is a little hare, but he has a nice warm bast hut in which frosts are not terrible.

2. The fox, on the contrary, lived in an ice hut, which melted in the spring.

3. The hare and the fox are apparently neighbors who know each other - the hare is compassionate and lets the fox in, but soon something went wrong and it lost his house.

4. The bear and the wolf in nature are stronger than the fox, but why suddenly got they afraid of it? The rooster, on the contrary, is just a bird. It's weaker, but it was able to drive the fox out, and to win in the end. Why?

5. The bear and the wolf are presented in a fairy tale as they are, and the rooster has an additional inanimate object - a scythe. Why?

6. Why did Fox lie on the stove if it has a beautiful warm coat, and instead of looking out the window waiting for restless guests, at least?

7. The rooster did not go further after defeating the fox, but stayed to live in the house with the hare. Why?

Let's now try to think over a little the questions that come up. The plot develops around the assistance to a rather weak member of the community (in this case the one who lives in the forest) to get back his dwelling. At the same time, according to the text of the tale, each of those who he encounters on the way shows attention and respect both to him personally (they call him "Little Hare") and his problem and show readiness to help. But the victory does not come with the bear and the wolf. On the contrary, the dynamics of help go in the opposite direction, and not the strongest (bear) and the most aggressive (wolf) wins, but the weakest (rooster) one, the one who has a very important attribute, not related to the species component 
вой составляющей, и отсутствующий у всех действующих лиц кроме победителя (коса). Причём данный элемент не только страшен для лисы (враг), но и имеет большую ценность для главного героя, который в конечном итоге и приобщился к нему, приняв в свой дом.

Понимание приведённых выше, казалось бы, парадоксальных ситуаций приходит, возможно, при переходе на более высокий (в данном случае второй; первый - непосредственно сюжетная линия сказки) смысловой уровень представленного сюжета. Для этого мы должны повысить возрастной ценз слушателей с преимущественно мужской категорией - будущих защитников Отечества. Предъявление уже известной с детства сказки в этой аудитории будет вспрониматься по-новому. В качестве кого теперь вопринимается Заяц - молодого неопытного воина. Самоидентификация юноши, избравшего путь ратного дела, с главным героем (зайчик), позволяет ему понять на какое отношение он может рассчитывать от окружающих - доброе, понимающее, готовность помочь и научить. Кто такая Лиса - хитрый, коварный враг, способный захватить его дом (Родину). И борьба с сильным, коварным врагом требует от Воина многого. Он должен пройти по тропе (Пути) и постигнуть / приобрести три (триединство) качества Медведя, Волка и Петушка с косой. Здесь следует отметить, что указанная последовательная очерёдность появления героев по мере развития сюжета, имеет принципиальное значение, так как отражает Путь формирования воина, а образы лесных жителей и их атрибуты (коса) очень чётко символизируют физические и духовные качества, необходимые для настоящего защитника Отечества.

Исходя из такого понимания первоначального смысла сказки, вернёмся к её началу и попробуем сделать более глубокий анализ сути домов Зайца и Лисы.

Если наше предположение о Зайце как молодом неопытном воине верно, то становится и более понятен смысл крепкой лубяной ${ }^{1}$ избы. Она в этом случае символизирует род и родовые связи, поддержку, оказываемые члену сообщества, крепкий тыл, что даётся каждому члену семьи по рожде- and absent from all actors except the winner (scythe). Moreover, this element not only frightens the fox (enemy), but also has great value for the main character, who at the end joined him by inviting him into his house.

Understanding of the above seemingly paradoxical situations comes, perhaps, when moving to a higher (in this case, the second, as the first is directly the storyline of the fairy tale) semantic level of the plot presented. To do this, we must increase the age limit of students with a predominantly male category - future defenders of the Fatherland. Presentation of a fairy tale that they have known from childhood will be reimagined. Now the Hare is perceived as a young inexperienced warrior. The self-identification of a young man who has chosen the path of military affairs with the main character (the Hare) allows him to understand what kind of attitude he can count on to get from others - kind, understanding, willing to help and teach. The Fox now is a cunning, treacherous enemy, able to seize his house (homeland). And the fight against a strong, treacherous enemy requires a lot from the Warrior. He must go along the path and acquire three (trinity) qualities - the Bear, the Wolf and the Rooster with a scythe. It should be noted here that the indicated sequential order of the appearance of heroes as the plot develops is of fundamental importance, since it reflects the way of formation of a warrior, and the images of forest inhabitants and their attributes (scythe) very clearly symbolize the physical and spiritual qualities necessary for a true defender of the Fatherland.

Based on this understanding of the original meaning of the tale, let us return to its beginning and try to do a deeper analysis of the essence of the houses of the Hare and the Fox.

If our assumption of the Hare as a young inexperienced warrior is true, then the meaning of a strong bast ${ }^{2}$ hut becomes more clear. In this case, it symbolizes the clan and clan ties, the support provided to a member of the community, the strong support that is given to each member of the family by birth. Fox House does not have such qualities - it is temporary, unreliable in nature, without strong support, and not able to

\footnotetext{
${ }^{1}$ Лубяная - сделанная не непосредственно из луба (луб - подкорье, пласт коры с внутренней волокнистой частью молодых лиственных деревьев, преимущественно липы), а из дерева, бруса, очищенного от коры до подкорья, луба. Лубом так же могли обшивать брус домов для защиты и утепления. Поэтому избушка могла быть обычной деревянной или дополнительно обшитой лубом.

${ }^{2} \mathrm{~A}$ bast hut doesn't mean it is actually made of the bast (the bast is beneath the bark, a layer of bark with an inner fibrous part of young deciduous trees, mainly linden), but from a tree, a timber, peeled from the bark to the inner part, and bast. They could also sheathe timber on houses with the bast for protection and warming. Therefore, the hut could be an ordinary wooden one or additionally sheathed with bast.
} 
нию. Дом Лисы не имеет таких качеств - носит временный, ненадёжный характер, не имеющий крепкого тыла, и не способный защитить.

С другой стороны, понятие Дома, не всегда ограничивается абстрактными представлениями, даже имеющими высокий духовный смысл. Традиции русских единоборств дают и другое определение дома, позволяющее воину примерить его на себя, что имеет большое значение при непосредственной физической подготовке и овладению навыками рукопашного боя. С позиций тела, Дом это пространство вокруг бойца, ограниченное дистанцией от туловища до первого сустава вытянутой руки (локтевого) и ноги (коленного). Дальняя точка этой дистанции (локтевой и коленный суставы) в этом случае называется «порогом», где и нужно встречать гостя (врага). В практическом плане это имеет важный посыл - встреча удара противника дальше, вне этой дистанции даёт наибольший шанс ухода с линии удара или его отражения («съёма»). Проникновение противника «за порог» (внутрь дома), напротив, резко повышает риск ранения или смерти.

Другой более глубокий смысл Дома - это понимание его как вместилища внутреннего, духовного мира воина (голова, сердце). Если прошедший за линию «порога» удар противника несёт физические страдания, то проникновение во внутренний мир бойца - страха, сомнений, растерянности др., может вести к отказу от борьбы, его духовной гибели, предательству. В этом случае Лиса, поселившаяся в лубяной избе (в душе), символизирует и духовный надлом Зайца - неспособность противостоять и продолжать борьбу.

Лиса - хитрый коварный враг, но живёт в ледяной избе, которая тает весной. Почему? Можно смело предположить, что этот образ имеет достаточно чёткие исторические характеристики войн прошлого (вплоть до XX века) - сезонность начало военных кампаний весной и летом, окончание их, и переход армий на зимовки в осеннезимний период. С другой стороны, Лиса, живущая в ледяной избе, может ассоциироваться с холодной расчётливостью и безжалостностью, «смертельной» опасностью для завоёванного народа (как тут не вспомнить бедного Кая, сердце которого замёрзло после поцелуя Снежной королевы и перестало чувствовать и любить, а из памяти ушли все добрые воспоминания).

Последний аспект (отношения в прошлом) может вполне иметь значение и для анализа сюжета нашей сказки. Вспомним, что Заяц, пожалев, сам впустил Лису в дом переночевать, сочувствуя по- protect.

On the other hand, the concept of Home is not always limited to abstract representations, even those that have high spiritual meaning. The traditions of Russian martial arts give another definition of the house, allowing the warrior to try it on himself, which is of great importance in direct physical training and mastery of hand-tohand fighting skills. From the position of the body, the Home is the space around the fighter, limited by the distance from the body to the first joint of the outstretched arm (elbow) and leg (knee). The far point of this distance (elbow and knee joints) in this case is called the "threshold", where you need to meet the guest (enemy). In practical terms, this has an important message meeting the enemy's strike farther, outside this distance, gives the greatest chance to withdraw from the strike line or reflect it ("lift"). Penetration of the enemy "beyond the threshold" (inside the house), on the contrary, greatly increases the risk of injury or death.

Another deeper meaning of the House is its understanding as a container for the internal, spiritual world of a warrior (head, heart). If the enemy's strike passing beyond the "threshold" line carries physical suffering, then penetration into the internal world of a soldier - fear, doubt, confusion, etc., can lead to the abandonment of the struggle, its spiritual death, betrayal. In this case, the Fox, who settled in the bast house (in the soul), also symbolizes the spiritual breakdown of the Hare - the inability to resist and continue the struggle.

The fox is a cunning, insidious enemy, but she lives in an ice hut that melts in the spring. Why? One can safely assume that this image has quite clear historical characteristics of the wars of the past (up to the 20th century) - seasonality - the beginning of military campaigns in spring and summer, their end, and the transition of armies to rest for the autumn-winter period. On the other hand, the Fox living in an ice hut can be associated with cold prudence and ruthlessness, a "deadly" danger for the conquered people (how can we not remember poor Kai, whose heart froze after kissing the Snow Queen and ceased to feel and love, and all good memories are gone).

The latter aspect (relations in the past) may well be important for the analysis of the plot of our tale. Recall that the Hare regretted letting Fox into the house for the night, sympathizing with the fate of her melted house. In this case, the Fox lived nearby, she did not come out of nowhere. That is, the Hare was familiar with her 
стигшей судьбе её растаявшего дома. При этом Лиса проживала рядом, она не пришла из ниоткуда. То есть Заяц был с ней знаком и не видел угрозы, пригласив в дом. Лиса его коварно обманула. Выгнала и поселилась в его доме.

Интересен вопрос: - Где именно и в какой части дома поселилась Лиса? Сказка нам даёт совершенно чёткий ответ - на печи. Интересно, что об этом знает и отмечает каждый действующий персонаж: Лиса сообщает - «... лежу на печи», а каждый из трёх помощников Зайца, пытаясь её прогнать, прямо указывают - «... поди, Лиса, вон с печи...» (а не как следовало бы - «из дома»). Эта ситуация, отмеченная неоднократно, может указывать на её особое символическое значение, для понимания которого можно обратиться к другой русской народной сказке «Колобок». В ней Бабушка, инициируемая Дедушкой, печёт колобок. Вначале это просто хлеб, но согласно развитию сюжета он вдруг приобретает человеческие качества, называя себя при встрече с лесными жителями Колобком (это уже имя). По этому сюжету становится понятно, что печь печёт не только хлеб, необходимый для жизни, но и саму жизнь, символизируя женское начало, где пекут людей, человеческий род. Ассоциации: женщина - дети - печь - очаг очень близки и понятны. Дети в русских избах буквально растут на печи, которая их кормит и греет, а при необходимости - спасает /или испытывает на взрослость и самостоятельность, предлагая испечь пироги (например, в печи прячется главная героиня сказки Гуси-Лебеди и т.д.). Таким образом, русская печь - это всё, что касается продолжения рода, его увеличения и сохранения.

Почему Лиса, войдя (завоевав) в дом, расположилась именно на печи? Очевидно, что не с целью погреться - уже весна, тепло, да и шуба у Лисы из лисьего меха, тёплая. Дело в другом. Лиса хитрый, коварный враг, а на момент вхождения в Дом она становится Завоевателем, покорителем другого народа. Смена статуса определяет и новые цели при соответствующих возможностях - контроль над покорённым народом. Теперь только от нового Верховного правителя зависит - будет или нет развиваться (размножаться) этот народ, какие ценности станут внедряться в сознание и т.д. Отечественная история свидетельствует о том, что периоды завоевания сопровождались разной степенью убыли населения (объективный показатель), не говоря о разрушениях и страданиях.

Итак, теперь Лиса - Завоеватель. Народ покорён и контролируется. Заяц изгнан, страдает, и начинает идти по Пути Воина. Первый на этом Пу- and did not see the threat by inviting her to the house. The fox deceived him insidiously, expelled him and settled in his house.

Here comes an interesting question: Where exactly did the Fox settle? The tale gives us a very clear answer - on the stove. It is interesting that every character knows and notes that: the Fox informs: "...I am lying on the stove", each of the three Hare's assistants who try to drive her away tell her directly - "...leave the stove, Fox..." (and not "leave home", as it should be). This situation, noted repeatedly, may indicate its special symbolic meaning, that can be observed in other fairy tales like "The Little Bun". There, the Grandma, initiated by the Grandpa, bakes a bun. It was just bread, but as the story goes, it acquires human qualities and when meeting other forest inhabitants it calls itself the Little Bun (this is already a name). This plot shows that the oven not only bakes the bread necessary for life, but it also 'bakes' life, symbolizing the feminine origin, where people, the human race, are baked. Associations: a woman - children - oven - hearth are very close and understandable. In Russian huts children literally grow on the oven which feeds and warms them, and when the time comes it saves them or tries them out for an adult and independent life, offering to bake a pie (for example, the main character of fairy tales Geese-Swans hides in the oven, etc.). Thus, the Russian stove is all that relates to the continuation of the kin, its expansion and preservation.

Why did the Fox having entered (conquered) the house located herself precisely on the stove? Obviously, not with the goal of warming up - it's already spring, it's warm, and the Fox's fur coat is warm. There is a different point here. A fox is a cunning, treacherous enemy, and at the moment of entering the House she becomes a Conqueror, a conqueror of another nation. The change of status also defines new goals with the corresponding opportunities - control over the conquered people. Now it depends only on the new Supreme Ruler whether or not this people will develop (multiply), what values will be introduced into their consciousness, etc. National history indicates that periods of conquest were followed by varying degrees of population decline (an objective indicator), not to mention destruction and suffering.

So now the Fox is the Conqueror. The people are defeated and controlled. The Hare is expelled, suffers, and begins to follow the Path of the Warrior. The first on this Path comes the 
ти - Медведь. Что символизирует Медведь - силу. И именно он первым встречается на пути главного героя, предлагая свою помощь и поддержку. Воин должен развиваться физически, быть сильным и выносливым. Заяц (Воин) проходит этот этап подготовки - приобретает качества Медведя. Но можно ли только силой победить хитрого и коварного врага? Народная мудрость и опыт, на примере сказки, говорит, что этого недостаточно - Лиса только угрозами расправы одержала победу над теперь уже физически сильным (при поддержке Медведя) противником. Физическая подготовка лишь первый уровень обучения воинскому искусству. Что ещё? Это духовное воспитание. Формирование у воина любви к Отечеству, начиная с ближайшего окружения, малой Родины. Способность сохранить верность своему народу, вере, даже в самой тяжелой ситуации. Для этого нужны смелость, храбрость, умение хлоднокровно действовать в трудной боевой обстановке, нетерпимость к трусости (качества, символизирующие Волка). И это следующий этап воспитания воина. Но достаточен ли он? Можно ли победить хитрого коварного врага, будучи не только сильным, но и смелым? Сказка нам даёт совершенно точный ответ - нет... Нужно что-то ещё... Ещё одно качество, которое в сказке символизирует Петушок.

Как было отмечено выше, этот персонаж резко отличается от всех других героев - он самый слабый, принадлежит к виду пернатых (птица) и в придачу имеет внешний атрибут из неживого мира - косу. И именно эти качества указывают на их особый смысл, раскрытие которого на самом деле не вызывает особых трудностей. Так в русской народной традиции «красный петух», «пустить петуха» ассоциируются с пожаром, как правило, несущим угрозу, смерть и разорение, беду, что имело очень большое значение для городов деревянного зодчества, а коса лишь более точно конкретизирует образ как символ смерти. Недаром и А.С. Пушкин [2] наделил Золотого Петушка очень близкими качествами: сторожил Царство от нашествия врагов, несущих угрозу и смерь, и в тоже время был причиной кончины Царя Додона, не пожелавшего расставаться с красавицей из Шемаханского царства. Золотой Петушок разрешил спор двух старцев ударом клюва в темя Додона, прервав его земной жизненный путь и направив в реку Лету.

Встреча Зайчика с Петухом в нашей сказке так же стала ключевым и завершающим этапом развития сюжета, что указывает на важность этого сим-
Bear. What the Bear symbolizes is power. And it was he who first met on the path of the main character offering his help and support. A warrior must develop physically, be strong and tough. The Hare (Warrior) goes through this stage of preparation - acquires the qualities of the Bear. But is it only possible to defeat a cunning and treacherous enemy by force? People's wisdom and experience, using the example of a fairy tale, says that this is not enough -only with threats of reprisal the Fox defeated the now physically strong (with the support of the Bear) opponent. Physical training is only the first level of training in military art. What else? This is spiritual education. The formation of a warrior's love of the Fatherland, starting with the immediate environment, the small homeland (the local community). That would symbolize the ability to remain faithful to your people, faith even in the most difficult situations. This requires courage, the ability to act cold-blooded in difficult combat situations, intolerance for cowardice (qualities that symbolize the Wolf). And this is the next stage in the education of a warrior. But is that enough? Is it possible to defeat a cunning insidious enemy, being not only strong, but also brave? The fairy tale gives us an absolutely accurate answer - no... We need something else ... Another quality that the Rooster symbolizes in the fairy tale.

As noted above, this character is very different from all other characters - he is the weakest, belongs to the species of feathered (a bird) and in addition has an external attribute from the inanimate world - a scythe. And it is precisely these qualities that indicate their special meaning, understanding of which in fact does not cause any particular difficulties. For example. in the Russian folk tradition expressions like "a red rooster" or "to let the rooster" are associated with fire, which usually poses a threat, death and ruin, misfortune, which was very important for the cities of wooden architecture, and the scythe only makes the image more accurate as it is also a symbol of death. No wonder that A.S. Pushkin [2] endowed the Golden Rooster with very similar qualities: he guarded the Kingdom from the invasion of enemies who could bring threat and death, and at the same time he himself caused the death of King Dodon, who did not want to let go the beautiful woman from the Shemakhan kingdom. The Golden Rooster resolved the dispute between the two elders by beaking Dodon in the crown, interrupting his earthly life and sending him to the Leta River.

The meeting of the Hare and the Rooster in 
вола. Суть - принятие воином факта собственной смерти как возможного и/или неизбежного финала на пути ратного дела. Именно преодоление страха смерти, способность отдать жизнь за собственный народ, Отечество (Дом), делает из мужчины настоящего Воина. Дальнейший, уже совместный путь обоих героев, особенно факт поселения Петушка в Доме (в душе) указывает на прохождение третьего уровня посвящения в Воины - духовного перерождения, и принятие Зайчиком такой судьбы. Это не могло не отразиться и на поведении Завоевателя хитрого коварного врага. Увидев Воина, идущего на смертельный бой, способного пожертвовать своей жизнью, реальную (смертельную) угрозу, Лиса убегает, бросая Дом и завоёванный народ. Заяц возвращается в своё жилище, но он уже другой - он Воин, Защитник и Победитель. Смерть (в лице Петушка), ходившая рядом с ним на врага, остаётся при нём, становясь частью его внутреннего духовного мира («все измеряется смертью»).

\section{Заключение.}

Представленный анализ сказки не претендует на абсолютную однозначность её толкования и безусловность доводов, но позволяет обратить внимание думающего читателя на необходимость изменения отношения к национальной устной и письменной традиции. Это лишь попытка показать важность и необходимость отказа от часто предвзятого представления о наивности сюжетов и простоте смысловой нагрузки народных произведений, как рассчитанных в основном на детскую аудиторию. Сохранение культурного наследия подразумевает не только уважительное отношение, но и его изучение, анализ, возможность дальнейшего развития. При прочтении сказок важно понимание ключевых моментов сюжета и наличия системы многоуровневого кодирования, проявляющей понять заложенные в них базовые представления, лишь при точной социальной, временно̀й, возрастной или другой системе локации. Лишь такой подход позволит прикоснуться к истинным «таинствам знаний» и накапливаемой веками народной мудрости, понять тонкости и особенности национальной культуры.

Передача знаний и традиций следующему поколению является обязательным условием сохранения национальной культуры. Но это подразумевает необходимость поддержания традиций многоуровневого, многоканального обучения. При этом раннее детство - это лишь начало вовлечения ребёнка в национальную культуру. К сожалению, для многих, рассказанная в детстве сказка в лучшем our fairy tale also became the key and final stage in the development of the plot in our fairy tale, which indicates the importance of this symbol. The bottom line is the acceptance by the warrior of the fact of his own death as a possible and/or inevitable ending on the path of military affairs. It is the overcoming of the fear of death, the ability to give life for one's own people, the Fatherland (Home), makes a man a real Warrior. The further, already joint path of both heroes, especially the fact that the Rooster settles in the House (in the soul) indicates that the Hare passed successfully the third level of initiation into the Warriors - spiritual rebirth and the adoption of such a fate. This could not leave the behavior of the Conqueror unchanged - a cunning, insidious enemy. When seeing the Warrior going to a mortal battle, capable of sacrificing his life, that is a real (deadly) threat, the Fox runs away, leaving the House and the conquered people. The Hare is returning to his home, but he is already different - he is a Warrior, Defender and Conqueror. The Death (represented by the Rooster) that sided him when facing the enemy, remains with him, becoming part of his inner spiritual world ("everything is measured by death").

\section{Conclusion}

The presented analysis of the tale does not pretend to be absolutely unambiguous in its interpretation and unconditioned with the arguments given, but it allows the reader to pay attention to the need to change attitudes towards the national oral and written tradition. This is just an attempt to show the importance and necessity of abandoning the often prejudiced idea of the naivety of the plots and the simplicity of the semantic load of folk works, as designed mainly for children. The preservation of cultural heritage implies not only respectful attitude, but also its study, analysis, and the possibility of further development. When reading fairy tales, it is important to understand the key points of the plot and the presence of a multi-level coding system, which shows understanding of the basic ideas contained in them, only with an accurate social, temporal, age or some other location system. Only such approach will allow one to touch the true "mysteries of knowledge" and the folk wisdom accumulated over centuries and allows to understand the subtleties and characteristics of national culture.

The transfer of knowledge and traditions to the next generation is a prerequisite for the preservation of national culture. But this implies the need to maintain the traditions of multi- 
случае остаётся добрым воспоминанием, и не имеет дальнейшего продолжения. Человек обычно сохраняет лишь малопонятную для взрослого сюжетную линию, и часто не в полном объёме. Если повезёт, то повторная встреча со сказкой будет спустя много лет, при чтении её со своими детьми и/или внуками. Редкие попытки анализа чаще будут вызывать непонимание, и неудачны, так как уже привычное логическое мышление не сможет вернуть детскую наивность и веру в чудеса. Лишь немногим накопленный жизненный опыт и чуткость позволят увидеть в кажущейся простоте сказочного произведения настоящую народную Мудрость, Уважение и Любовь, и передать их подрастающему поколению...

Литература / Reference:

1. Майорат / Энциклопедический словарь Брокгауза и Ефрона: в 86 т. (82 т. и 4 доп.). СПб., 1890-1907. [Majorat / Jenciklopedicheskij slovar' Brokgauza i Efrona: v 86 t. (82 t. i 4 dop.). SPb., 1890-1907.] (In Russ) level, multi-channel learning. At the same time, early childhood is only the beginning of the child's involvement in the national culture. Unfortunately, for many, the tale heard in childhood at best remains a good memory, and has no further continuation. An adult person usually retains only an obscure and often not full storyline. If you are lucky, you will come across the fairy tale again, in many years, when reading it to your children and/or grandchildren. Rare attempts to analyze fairy tales will often lead to non-understanding and failure, because the usual logical thinking will not be able to return child's naivety and belief in miracles. Only a few accumulated life experience and sensitivity will allow us to see in the seeming simplicity of a fairy tale a real folk Wisdom, Respect and Love, and pass it on to the younger generation ...

2. Пушкин А.С. Сказка о золотом петушке / Пушкин А.С. Полное собрание сочинений: В 10 т. Л.: Наука. Ленингр. отделение, 1977-1979. Т. 4. Поэмы. Сказки. 1977. С. 358-363. [Pushkin A.S. Skazka o zolotom petushke / Pushkin A.S. Polnoe sobranie sochinenij: V 10 t. L.: Nauka. Leningr. otdelenie, 19771979. T. 4. Po-jemy. Skazki. 1977. S. 358-363.] (In Russ)

\section{RUSSIAN FOLK TALE AS A MEANS OF EDUCATING A WARRIOR AND DEFENDER OF THE FATHERLAND}

\section{P.B. Zotov}

Tyumen State Medical University, Tyumen, Russia; note72@yandex.ru

\section{Abstract:}

An original analysis of the Russian folk tale "The Fox and the Hare" is presented. In the introductory part, the author noted a number of conditions required for the interpretation of fairy tales: the need to follow the original plot; preferred rejection of logical conclusions; the strict location of the fairy tale in a social group or conditions, the geography of the place or a specific historical interval, in relation to which the fairy tale will begin to reveal its true purpose. An analysis carried out according to these conditions showed that the primary plot of the fairy tale under study may have a deeper meaning and reflect the stages of education and training of the defender of the Fatherland. To defeat a cunning and treacherous enemy (Fox) by a young inexperienced warrior (Hare), you need to go through three stages / levels of preparation (Path): to become physically strong (Bear), brave and courageous (Wolf) and accept your own death as a likely outcome military affairs (Rooster with a scythe). In the course of the plot, individual elements of the fairy tale are also discussed (House, stove, etc.), which allows you to take a fresh look at a folk work known from childhood and understand its high spiritual meaning. In conclusion, the author notes that the analysis of the tale presented does not pretend to interpret the tale absolutely and unconditionally, but it allows to draw one's attention to the need to change attitudes towards the national oral and written tradition, the need to study it.

Keywords: bast hut, Fox and Hare, analysis of the tale "Fox and Hare", the psychological preparation of a warrior, fairy tale, Russian folk tale, analysis of the tale

Финансирование: Исследование не имело финансовой поддержки.

Financing: The study was performed without external funding.

Конфмикт интересов: Автор заявляет об отсутствии конфмикта интересов.

Conflict of interest: The author declares no conflict of interest.

Статья поступима / Article received: 12.10.2019. Принята к публикации / Accepted for publication: 06.03.2020.

Для цитирования: Зотов П.Б. Русская народная сказка как средство воспитания Воина и защитника Отечества. Девиантология. 2020; 4 (1): 92-101. DOI: 10.32878/devi.20-4-01(6)-92-101

For citation: $\quad$ Zotov P.B. Russian folk tale as a means of educating a Warrior and defender of the Fatherland. Deviant Behavior (Russia). 2020; 4 (1): 92-101. (In Russ) DOI: 10.32878/devi.20-4-01(6)-92-101 